\title{
OBITUARIES
}

Obituaries should be submitted by email to Laura Pacey at I.pacey@nature.com.

All submitted obituaries should be 450 words maximum in length (apart from obituaries for past presidents of the BDA where the length should be 800 words).

Content of the obituary is down to the individual author, and the approval of the family should

be given for the obituary prior to submission to the $B D J$.

\section{BERNARD WOOLF BLOOM}

\section{1-2014}

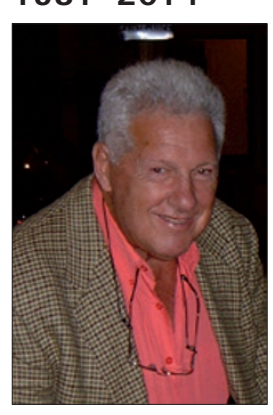

After 44 years in practice many of his original patients still remained.

Bernard continued his involvement in dentistry and with David established an orthodontic practice to help with the demand for this in the local area. Sadly Bernard suffered with Parkinson's disease dementia (Lewy body disease) for many years and his health deteriorated; although he fought on until his sad death in March 2014.

He was survived by his wife, Lucienne (but sadly for only 6 weeks), his beloved four boys Stuart, Philip, Nicholas and David, and eight grandchildren. He will be sadly missed but still very much loved.

David Bloom

his native Hertfordshire with his now wife Lucienne and established a practice in the family home. Working all hours, often until 10 o'clock, meant the practice was rapidly very successful and so he relocated to dedicated premises. This meant that patients would no longer be greeted by Bruno, the family St Bernard dog. Patients would often famously tell these stories to his son David some 40 years later.

He was ahead of his time in that he would often work two or three chairs, allowing examinations to be done while the local was taking effect. He had a hygienist Alison Williamson from the early 70s and practised indirect restorative quadrant dentistry (crown and bridge at the time) in a time when extensive caries meant large amalgams where the norm. He also had a 'spaceline' chair that also allowed four-handed dentistry when many colleagues were still practising with little if any chairside assistance. He was proud to practice within the NHS (as well as privately) for over 40 years.

In 1990 his youngest son David, who also qualified at Newcastle and was mentored by Bernard's contemporary and legend of Newcastle Dental School, Dr Izydor Geffner (or Geffy to those that knew him), joined Bernard and the practice was re-branded as Bloomsbury Dental and relocated. Bernard and David continued working together until Bernard's eventual retirement in 2001. in front of external examiners and the clinical arena but beyond. Promoted to a personal chair in 1973, he ensured the survival and success of the Belfast Dental School by establishing chairs in the six main dental specialities of the time. He served twice as Dean: 1979-1983 and 1984-1989.

Frank had a very good memory essential for a histopathologist - but the breadth of his interests was enormous: sport, international affairs, philosophy, art, history, politics, religions; nothing seemed beyond his ken or comment. His social conscience led him to contribute actively to achieve stability and harmony in Northern Ireland; following the Anglo-Irish Agreement in 1985 he became a member of the Police Authority, working to improve the acceptance of the Royal Ulster Constabulary (RUC) across the community. This work was not without its difficulties - he described the attention that this brought him personally from paramilitary organisations as 'a little unsettling' - but he knew that there was no alternative. He retired in 1991 to his home town of Cahir, Co. Tipperary and devoted much of his newfound free time for the next 10 years to a drugs and alcohol rehabilitation project there.

Frank was a very private man. He rarely spoke of his family - and only so that he could change the subject - but he was devoted to them. His brother Michael, a general medical practitioner in Bristol, predeceased him by more than 10 years but Frank retained very close links with his nephew James and his nieces Catherine, Liz and Claire, and their children. On hearing of his passing, one of my classmates remarked: 'he was simply the best teacher I ever had.'

Never a truer word.

Séamus S. Napier 